\title{
Building trust between growers and market agents ${ }^{1}$
}

\begin{abstract}
In the absence of the auction as the principal mechanism for setting price in the Perth fresh fruit and vegetable market, there is a great deal of distrust between growers and the market agents who receive and distribute their produce. While most growers generally transact with more than one market agent, satisfaction with the exchange builds trust. Trust is facilitated where the grower and the market agent share similar goals. To reinforce trust, growers prefer to transact with those market agents who are prepared to invest in their relationship with the grower. Conversely, the market agents propensity to act opportunistically, to exercise power and to withhold information from the grower will have a significant negative impact on the trust that develops between growers and market agents.
\end{abstract}

Key words: trust, relationships, fresh produce

\section{Introduction}

In Perth, Western Australia, the traditional ways of conducting business in the fresh produce industry are rapidly changing. With supermarkets now accounting for approximately $70 \%$ of retail sales, competition between the major retail chains is intensifying. With the fresh produce section being the major driving force in sales across the entire shop floor, retailers are being forced not only to reduce costs, but to give greater consideration towards product quality as a means of attracting and retaining more discerning consumers.

Historically, retailers have purchased the fresh fruit and vegetables they require from the central wholesale market, the Perth Metropolitan Market. First established in 1926 under the Metropolitan Markets Act No. 55, the Perth Metropolitan Market Trust was appointed as the corporate body to manage the Perth Metropolitan Market (Caddy, 1978). The Trust owns and maintains all the buildings in the central market, whereupon it leases out space to various market agents who dispose of the fresh produce consigned to the market by the many growers spread throughout the state. These market agents are licensed under the Metropolitan Market Trust Lease and Covenant to conduct the business of commission agents. Keen rivalry and competition between the market agents has generally seen growers benefit from the market agent's endeavours to develop their business enterprises.

However, more recently, as the major retailers have moved towards procuring greater quantities of the fresh produce they require directly from growers, the market agents' share of the business has declined. As each attempts to offer growers the highest price in order to secure their business, they must, on the other hand, provide their customers with a cost effective and reliable supply of fresh produce. In order to reduce costs, most have abandoned the auction as the principal price setting mechanism in the market. With private negotiation becoming the primary means for establishing price, growers must rely to a much greater extent upon the integrity of their trading partners.

\footnotetext{
${ }^{1}$ Batt, Peter J. (2003), Building trust between growers and market agents. Supply Chain Management: an International Journal, Vol 8 (1), 65-78.
} 
Unlike the auction, where the price at which the produce is sold is public knowledge and, to some extent, where the identity of the buyer is revealed, the lack of transparency inherent in private negotiations has resulted in an underlying atmosphere of distrust between the growers and market agents. Growers feel there is inadequate disclosure of information about sales and, in particular, how the net price was calculated. Among other things, growers want to satisfy themselves that the market agents margins are not excessive and that any other deductions are legitimate. Furthermore, many growers are dissatisfied by the reporting of a net price across a range of different qualities, sizes and varieties which obscure the market signals (Chamber of Fruit and Vegetable Industries, 1999).

Additional problems have arisen with regard to the growers desire to know who purchased their produce. Here, growers want to verify the selling price, determine whether the buyer was a related party and in other instances, to contact the buyer for information about the consumer acceptability of the produce. Understandably, market agents have serious concerns about identifying the buyer for fear that the growers, once they know who purchased their produce, will take steps to deal directly with the retail buyer. Furthermore, in discussion with other parties, there is always the risk that growers may reveal commercially sensitive information, which could enable other parties to secure the market agent's business.

Since a number of the market agents regularly sell produce to related or subsidiary companies who are involved in value-added activities such as grading and repacking produce for supermarket buyers or the food service sector, growers fear that such transactions often occur at less than the best available price.

Furthermore, many growers have concerns that a proportion of their produce has been sold at the Saturday morning clearance market. Here the major issues relate to whether the produce could have been sold at a better price during the week and whether the produce is of sufficient quality to be retained for sale the following week. Since a large proportion of the produce sold at the Saturday morning clearance market is purchased by consumers and paid for in cash, growers have concerns as to whether the proceeds of the sale have been properly reported.

Finally, while growers can be expected to transact with that market agent who offers the highest price, receiving good prices is no guarantee of getting paid. Most market agents pay the grower 14-21 days after the produce has been received. As a result of rationalisation in the supply chain and financial mismanagement, several market agents have collapsed leaving growers as the major creditors.

In an environment where distrust and disputation is common between the growers and market agents, this study sought to investigate the various ways in which the market agents' could build trust in their relationship with growers. In what is a very mature industry and arguably even a declining industry, it is widely recognised that customer retention is more cost effective than customer creation (Fornell, 1992; Kalwani and Narayandas, 1995). From the market agents' perspective, being able to attract and retain a greater share of the growers business will have significant positive benefits on the profitability of their enterprise and, in turn, their propensity to attract and retain retail customers. From the growers' perspective, trust is expected to reduce much of the risk and uncertainty currently present in their transactions with market agents. 


\section{Trust: a theoretical foundation}

For any particular potential exchange, trust will be critical if two situational factors are present; (i) risk and (ii) incomplete buyer information (Hawes, Mast and Swan, 1989). Since most sales transactions present some degree of risk and uncertainty, trust acts as an information resource that reduces the perceived threat of information asymmetry and performance ambiguity. Trust enables exchange partners to adopt schemas which leave them free to act without trying to process more information than they are capable of handling (Tomkins, 2001), or where they are unable to acquire sufficient information about future events (Selnes, 1998).

In the absence of complete information, trust has been conceptualised as the willingness of an exchange partner to make oneself vulnerable to the actions of another party, in the expectation that the other party will perform a particular action (Mayer, Davis and Schoorman, 1995). Trust involves various actions, voluntarily or freely undertaken, whereby one places oneself, or what one cares about, within the powers of another who, but for their good will, might impose harm upon oneself or those things one values (Brenkert, 2000). Trust is therefore a belief or an expectation that the vulnerability resulting from the acceptance of risk will not be taken advantage of by the other party in the relationship (Lane, 2000). These expectations may be calculative, value or norm based, or based on common cognitions.

Zucker (1986) describes trust between organisations in the context of process-based trust, characteristic-based and institutional-based trust. Process-based trust is derived from a social system of mutual obligations, where each partner has clear expectations of the other's behaviour. Characteristics-based trust is tied to specific individuals, where various demographic features serve as indicators of membership to a common cultural system with shared expectations. Institutional-based trust rests both on membership in a subculture within which clearly delineated expectations are held and from various intermediary mechanisms that the trustee undertakes to protect the interest of both partners.

In the context of long-term buyer-seller relationships, Sako (1992) finds it necessary to differentiate between contractual trust, competence trust and goodwill trust. Contractual trust rests on the moral norm of honesty and keeping promises. Competence trust is based on the expectation that the trading partner will perform its role competently. Goodwill trust is described as the willingness of the exchange partner to do more than expected. Someone who is worthy of goodwill trust is dependable and can be granted some discretion, for they can be trusted to take initiatives while refraining from taking unfair advantage of the partner.

However, trust is envisaged both between individuals and organisations. Swan, Trawick and Silva (1985) indicate how competence, customer orientation, honesty, dependability and likeability are the key dimensions in developing trust between sales representatives and customers. Moorman, Deshpande and Zaltman (1993) suggest that the interpersonal factors that most affect trust include perceived expertise, sincerity, integrity, tactfulness, timeliness and confidentiality. Mayer, Davis and Schoorman (1995) describe how ability, benevolence and integrity are the three characteristics that best explain trustworthiness.

When trust exists, both partners believe that long-term idiosyncratic investments can be made with limited risk because their opposite party will refrain from using their power to renege on contracts or to use a change in circumstances to obtain profits in their own favour (Ganesan, 1994; Doney and Cannon, 1997). Trust reduces the need for structural mechanisms of control 
(Achrol, 1997) and the partners learn to become more interdependent (Kumar, 1996). Trust increases the partner's tolerance for each other's behaviour, facilitating the informal resolution of conflict, which, in turn, allows the partners to better adapt to the needs and capabilities of the counterpart firm (Hakansson and Sharma, 1996). Buyers who trust their suppliers are less likely to use alternative sources of supply and are more likely to accept any short-term inequities which arise in the exchange relationship (Kumar, 1996).

\section{Building trust in long-term relationships}

Interpersonal trust in business-to-business relationships is rarely offered spontaneously, rather, it results from an extended period of experience with an exchange partner (Lane, 2000; Dwyer, Schurr and Oh, 1987; Anderson and Weitz, 1989). During this time, knowledge about the exchange partner is accumulated, either through direct contact, or indirectly through reliable third parties.

Where there is some uncertainty surrounding an exchange, buyers will, amongst other tactics, attempt to reduce the perceived risk by either splitting orders between several alternative suppliers or to purchase from well known suppliers with whom they have dealt in the past (Cunningham and White, 1973). Jackson (1985) and Anderson, Chu and Weitz (1987) demonstrate that buyers are strongly attracted to existing suppliers, for they are perceived as being less risky. Athaide, Meyers and Wilemon (1996) indicate that firms are more likely to purchase from suppliers who have supplied them in the past. While prior interaction may lead to high switching costs because of the various relationship investments the buyer has made (Jackson, 1985; Heide and John, 1990; Anderson and Weitz, 1992), prior experience provides suppliers with the opportunity to build credibility and trust (Dwyer, Schurr and Oh, 1987; Anderson and Narus, 1990). Over many transactions and after many years of ethical, honest behaviour, where a partner has repeatedly demonstrated trustworthiness, fairness and integrity at all times, the partner will be perceived as a reliable exchange partner (Weylman, 1996).

$H_{1}$ : The duration of the grower's relationship with their preferred market agent will have a significant positive impact on trust.

Trust building however occurs as a gradual process whereby the amount of trust conferred accumulates in small incremental steps (Lane, 2000). Exchange partners test whether the other party is trustworthy by providing opportunities to betray trust, gradually increasing the object of trust and the level of risk entailed (Ring and van de Ven, 1992). Luhmann (1979) argues that trust involves learning and that such learning processes are only complete when the person to be trusted has had the opportunity to betray trust but not taken it. Achieving a trusting relationship requires a deliberate strategy of forbearance with a view towards future pay-offs and accumulated evidence of non-reneging behaviour (Parkhe, 1993).

Nevertheless, even after some time, trust remains a very risky investment, due to the fact that the trustee may exploit the vulnerability of the trustor at any time (Lane, 2000). The risk of opportunism is always present in exchange relationships and is often very difficult to detect. Opportunism refers to the incomplete or distorted disclosure of information, especially calculated efforts to mislead, distort, disguise, obfuscate or otherwise confuse (Williamson, 1985). The incentive to engage in opportunistic behaviour arises because one party finds it advantageous to maximise their own gains at the expense of the relationship (Gundlach, Achrol and Mentzer, 1995). However, if either party in the relationship chooses to behave 
opportunistically and that opportunism is detected, it will provoke retaliatory behaviour. When trust is betrayed, the aggrieved partner will react with great emotional intensity and trust will be lost. With trust and confidence in the relationship undermined, the aggrieved party will seek to withdraw or to limit their commitment to the relationship.

$\mathrm{H}_{2}$ : Should the grower's preferred market agent engage in opportunistic behaviour, there will be a significant negative impact on trust.

While the absence of opportunism does not in itself lead to trust, over many repeated transactions, the exchange partners begin to understand each other's motives. Part of the process of building trust involves finding out how an exchange partner will behave in a certain situation (Humphrey, 2000). Over time, relational norms will evolve which reflect the partner's abilities to collaborate and work together (Frazier, 1983). High levels of ideological agreement, goal compatibility, satisfaction and the restrained use of power will ultimately contribute to high levels of cooperation. For as long as both partners see their goals being met by joint action, they will be motivated to maintain the relationship (Wilson and Moller, 1995). Both parties must agree that their goals, although not necessarily similar, are compatible, so that each party can achieve their own objectives as well as the objectives upon which the relationship has been built (Spekman and Celly, 1995). Dwyer, Schurr and Oh (1987) propose and Anderson and Weitz (1989) confirm that shared goals have a significant, positive influence on trust. Morgan and Hunt (1994) and Wilson (1995) indicate that if both partners do not share similar values, they are less likely to benefit from the relationship. More recently, McQuiston (2001) suggests that shared goals and objectives are critical to the success of the relationship.

$H_{3}$ : Where the grower and their preferred market agent share similar goals, there will be a significant positive impact on trust.

According to the disconfirmation of expectations model, customer satisfaction is the result of a comparison between a partner's performance and the focal firm's expectations (Oliver, 1980). Whenever performance exceeds expectations, satisfaction will increase. Satisfaction has been defined as the focal firm's cognitive state of being adequately rewarded for the sacrifices they have undergone in facilitating the exchange (Frazier, 1983). Channel members that are highly satisfied with the economic rewards that flow from their relationship perceive their partner as being more trustworthy (Geyskens, Steenkamp and Kumar, 1999).

Satisfaction with past outcomes indicates equity in the exchange (Anderson and Narus, 1990). Equity generally refers to the fairness or rightness of something in comparison to others (Halstead, 1999). Equitable outcomes provide confidence that neither party has been taken advantage of in the relationship and that both parties are concerned about their mutual welfare (Ganesan, 1994).

Mackenzie and Hardy (1996) propose that as satisfaction increases, so will trust. Satisfaction with an exchange will lead to some initial trusting behaviour. If the outcome is positive, as satisfaction increases, trust will increase and continue to build over successive transactions.

$H_{4}$ : As the grower's satisfaction in their transactions with their preferred market agent increases, there will be a significant positive impact on trust. 
Buyer-seller relationships can be regarded as an investment. An investment is the process in which resources are committed in order to create, build or acquire resources that may be used in the future (Easton and Araujo, 1994). Through interacting with other firms and committing resources to specific relationships, firms have the opportunity to use relationships as a resource for the creation of other resources, product adaptations and innovations, process improvements, or to provide access to third parties (Hakansson and Snehota, 1995).

If a firm wishes to improve its relationship with another to achieve future benefits, then in all probability, the firm will need to commit various resources to the relationship, whether expressed in terms of managerial or sales force time, product or service development, process, financial or administrative adaptations (Ford, McDowell and Tomkins, 1996). Any resource committed above and beyond that required to execute the current exchange transaction can be regarded as an investment (Campbell and Wilson, 1996).

However, many of these investments are limited to a range of business opportunities and may be specific to a potential trading partner. Thus, the extent to which the firm is exposed to potential loss is dependent upon the asset specificity. Asset specificity refers to the ease with which an investment can be redeployed to alternative uses or alternative users without incurring a significant loss in value. Such relationship specific investments are seldom redeployable, or at least, have a substantially reduced value in an alternative relationship, thus exposing the firm to the possibility of exploitation by an opportunistic trading partner (Williamson, 1985; Heide and John, 1988; Anderson and Weitz, 1992).

Williamson (1985) suggests that investments stabilise relationships by altering the firm's incentive structure. By making relationship specific investments, the firm creates an incentive to maintain the relationship. Engaging in opportunistic behaviour and thereby risking the dissolution of the relationship is contrary to the self-interest of a channel member, for if the opportunism is detected and the relationship terminated, the investment may not have generated adequate returns (Lohtia and Krapfel, 1994). Furthermore, the making of such relationship specific investments may also provide a powerful signal to the other party. Observing the other party's pledges causes the channel member to be more confident in the other party's commitment to the relationship, because the other party will sustain considerable economic loss if the relationship is terminated (Anderson and Weitz, 1992). Relationship specific investments offer tangible evidence that the supplier can be believed, that it cares for the relationship and is willing to make sacrifices having made such investments (Ganesan, 1994). In this regard, the making of relationship specific investments provides strong signals of the channel partner's trustworthiness.

$H_{5}$ : The extent to which the grower's most preferred market agent is willing to make relationship-specific investments will have a significant positive impact on trust.

However, the making of relationship specific investments and subsequent locking-in of channel partners is not sufficient in itself to develop a long-term relationship (Ganesan, 1994). Long-term relationships bound only by dependence and investments may signify forced collaboration rather than cooperation. The extent to which this occurs (or does not occur) is determined by the relative power one firm holds over another, either because of the position of authority it commands, or the extent to which the partner is dependent upon it (Frazier, 1983). Pfeffer and Salancik (1978) suggest that a firm with a high level of power in both an absolute and relative sense will be relatively successful in influencing associated firms. 
However, the manner in which the more powerful partner chooses to use its power will have a significant impact on the relationship. If the more powerful firm is perceived to be using its power to achieve collective goals and does not impede the other in attaining its desired rewards, a high level of goal compatibility will exist. Conversely, if the firm is perceived to frequently pressure the other into taking actions which are against its own best interests, conflict will inevitably result. Partners will resist further influence attempts and try to enhance their power at the expense of the other.

$H_{6}$ : The exercise of coercive power by the grower's preferred market agent will have a significant negative impact on trust.

\section{Methodology}

Using a list provided by the Western Australian Chamber of Fruit and Vegetable Industries, all 1,260 fresh fruit and vegetable growers dealing with the market agents in the Perth Metropolitan Market were asked to complete a mail questionnaire. Since the study was undertaken with the support of the Perth Metropolitan Market Trust, the questionnaires were despatched with the grower's complementary copy of Market News, a quarterly publication advising industry of trends and events in the fresh produce industry. To facilitate responses, a self addressed reply paid envelope was included.

Growers were first asked to respond to a number of open-ended questions about the nature of their business and the nature of their relationship with their most preferred market agent, the duration of that relationship and whether the growers intended to continue the relationship. Growers were then asked to respond to 26 prepared statements about the nature of their relationship with their preferred market agent on a 7 point Likert scale from 1 (I disagree a lot) to 7 (I agree a lot). Information was sought on the growers satisfaction with the exchange, trust, power/dependence, goal compatibility and the various relationship specific investments the preferred market agent made to maintain the relationship. The various item measures were developed from the literature reported by Anderson and Narus (1990), Anderson and Weitz (1992), Athaide, Meyers and Wilemon (1996), Doney and Cannon (1997), Ford (1984), Frazier (1983), Frazier, Gill and Kale (1989), Heide and John (1988), Ganesan (1994), Gundlach, Achrol and Mentzer (1995) and Morris, Brunyee and Page (1998).

The various item measures were then analysed using principal component analysis (with Kaiser normalisation and varimax rotation). Those items with factor loadings below 0.5 or with cross-loadings greater than 0.4 were excluded (Nunnally, 1978). Further clarification of the contribution each item made to the corresponding factor was achieved by applying the reliability coefficient (Cronbach, 1951). The resultant factor scores were then regressed against the dependent variable (trust) in order to test the hypothesises.

Trust was assessed by 7 items based on the literature reported by Anderson and Narus (1990), Anderson and Weitz (1992), Doney and Cannon (1997), Ganesan (1994), Moorman, Deshpande and Zaltman (1993) and Morgan and Hunt (1994). Factor analysis produced a single construct, which, capturing six of the item measures, explained $65 \%$ of the variance. With a Cronbach's alpha of 0.915, the construct was considered sufficiently robust (Nunnally, 1978) (Table 1). 
Table 1. The trust dimension.

\begin{tabular}{|l|c|}
\hline & Factor loading \\
\hline I have confidence in my most preferred market agent & 0.895 \\
\hline I trust my most preferred market agent & 0.876 \\
\hline My preferred agent always considers my best interests & 0.865 \\
\hline I believe the information provided by my market agent & 0.856 \\
\hline My preferred agent has the expertise to sell my produce & 0.761 \\
\hline My preferred market agent always keeps their promises & 0.737 \\
\hline My preferred market agent is not always honest with me* & -0.624 \\
\hline & \\
\hline Cronbach’s alpha & 0.915 \\
\hline
\end{tabular}

* item deleted

\section{Results}

A total of 196 responses were received from growers. While a response rate of just $16 \%$ was considered disappointing, responses were received from a broad range of fresh fruit and vegetable growers from throughout the state. Most growers cultivated a wide range of temperate (64\%) and tropical fruit crops (10\%), with some $15 \%$ cultivating both fruit and vegetable crops. Vegetable growers comprised just $8 \%$ of respondents.

While the majority of farms (65\%) were smaller than 10 hectares, on the basis of the growers production estimates, collectively, the sample produced some 45,000 tonnes of fresh fruit and vegetables. With the Australian Bureau of Statistics (2000) estimating total fresh fruit and vegetable production in Western Australia to approach 400,000 tonnes per annum, it was apparent that the sample was representative of just $11 \%$ of the state's production.

Further estimates of the response bias were achieved by following the procedure suggested by Armstrong and Overton (1977). For all 33 item measures, a t-test was performed to compare early (145) and late (51) respondents. No significant differences between any of the item means were detected.

Most growers (98\%) sold all or at least some proportion of the fresh fruit and vegetable crops they harvested through one or more market agents in the Perth Metropolitan Markets. However, only $54 \%$ of growers sold more than $71 \%$ of their produce through their most preferred market agent. While 51\% of growers dealt with more than one market agent, additional sales outlets included direct sales to retailers (28\%), processors (19\%), cooperatives (15\%), exporters (11\%) and consumers (15\%).

The major reason for trading with more than one market agent was to obtain a competitive analysis, thereby assuring the grower that the preferred market agent was treating them fairly and equitably and could be trusted (28\%). Other reasons given for trading with more than one market agent included access to different markets (11\%), to spread the risk $(10 \%)$ or to dispose of surplus production (8\%). In other instances, since most growers produced a range of products, it was necessary to sell to another market agent because the preferred market agent did not handle the commodity (13\%). 
In choosing between alternative market agents, the most frequently cited response from growers was the market agent's reputation in the market for being trustworthy and reliable (39\%). Growers preferred to transact with those market agents who provided the best returns (31\%). Since most market agents paid the growers 14-21 days after the produce was received, other financial considerations included favourable terms of repayment (22\%) and financial stability (13\%). Other criteria included good service (21\%), good market knowledge (13\%) and the market agent's attitude towards the grower. Growers preferred to deal with those market agents who were approachable and with whom they were able to develop a good rapport (10\%).

From the grower's responses to the 26 prepared statements, principal component analysis produced six factors that collectively explained $66 \%$ of the variance (Table 2 ).

Table 2. Results of principal component analysis

\begin{tabular}{|c|c|c|c|}
\hline & Mean & SD & $\begin{array}{l}\text { Factor } \\
\text { Score }\end{array}$ \\
\hline \multicolumn{4}{|l|}{ Relational satisfaction } \\
\hline My preferred market agent treats me fairly and equitably & 5.05 & 1.62 & 0.834 \\
\hline My preferred market agent often meets my expectations & 4.81 & 1.48 & 0.818 \\
\hline I feel I am adequately rewarded by my preferred market agent & 4.62 & 1.79 & 0.812 \\
\hline My preferred market agent is quick to handle complaints & 5.06 & 1.55 & 0.766 \\
\hline $\begin{array}{l}\text { There is good cooperation between my preferred market agent and } \\
\text { myself }\end{array}$ & 5.14 & 1.55 & 0.763 \\
\hline $\begin{array}{l}\text { There is much conflict between myself and my preferred market } \\
\text { agent }\end{array}$ & 2.21 & 1.57 & -0.666 \\
\hline \multicolumn{4}{|l|}{ Cronbach’s alpha $=0.905$} \\
\hline \multicolumn{4}{|l|}{ Relational investments } \\
\hline $\begin{array}{l}\text { My preferred market agent seems interested in identifying more } \\
\text { suitable varieties for my growing environment }\end{array}$ & 3.51 & 1.91 & 0.821 \\
\hline $\begin{array}{l}\text { My preferred market agents suggests we should coordinate } \\
\text { production plans }\end{array}$ & 3.29 & 1.94 & 0.732 \\
\hline $\begin{array}{l}\text { My preferred market agent frequently informs me of product quality } \\
\text { and service requirements }\end{array}$ & 4.31 & 1.91 & 0.700 \\
\hline $\begin{array}{l}\text { My preferred market agent often advises me of potential market } \\
\text { demand }\end{array}$ & 4.68 & 1.95 & 0.652 \\
\hline $\begin{array}{l}\text { My preferred market agent spends time to ensure I know what the } \\
\text { market expects }\end{array}$ & 3.32 & 1.94 & 0.665 \\
\hline \multicolumn{4}{|l|}{ Cronbach's alpha $=0.842$} \\
\hline \multicolumn{4}{|l|}{ Power/dependence } \\
\hline $\begin{array}{l}\text { I have no choice other than to adhere to my preferred market agents } \\
\text { demands }\end{array}$ & 2.38 & 1.89 & 0.836 \\
\hline My preferred market agent has all the power & 2.88 & 2.11 & 0.819 \\
\hline My preferred market agent controls all the information & 3.49 & 2.10 & 0.731 \\
\hline Overtime I have become dependent on my preferred market agent & 3.11 & 1.96 & 0.700 \\
\hline Cronbach's alpha $=0.842$ & & & \\
\hline
\end{tabular}




\begin{tabular}{|l|c|c|c|}
\hline & Mean & SD & $\begin{array}{c}\text { Factor } \\
\text { Score }\end{array}$ \\
\hline Goal compatibility & & & \\
\hline $\begin{array}{l}\text { I frequently discuss my business plans with my preferred market } \\
\text { agent }\end{array}$ & 2.97 & 2.02 & 0.762 \\
\hline My preferred market agent and I share similar goals & 3.85 & 2.05 & 0.677 \\
\hline Cronbach’s alpha =0.659 & & & \\
\hline & & & \\
\hline Opportunism & & & \\
\hline My preferred market agent often acts opportunistically & 4.00 & 1.77 & 0.809 \\
\hline Duration & & & \\
\hline $\begin{array}{l}\text { I have been selling fresh produce through my preferred market } \\
\text { agent for a long time }\end{array}$ & 4.97 & 2.06 & 0.640 \\
\hline
\end{tabular}

Factor 1 (relational satisfaction) was derived from the grower's perceptions of having been treated fairly and equitably in the relationship (Frazier, 1983), of being adequately rewarded (Frazier, 1983) and from the market agent's performance in meeting the grower's expectations (Anderson and Narus, 1990). Relational satisfaction was enhanced by the speed at which the market agent responded to the grower's complaints (Ford, 1984), the extent to which there was good cooperation between partners (Anderson and Narus, 1990) and minimal conflict present in the relationship (Frazier, 1983).

Factor 2 (relational investments) was derived from the market agents various endeavours to identify more suitable varieties for the grower's environment (derived from Ford, 1994), the extent to which the market agent informed the grower of product quality and service requirements (derived from Athaide, Meyers and Wilemon, 1996), the extent to which the market agent was prepared to spend time with the grower to ensure they understood what the market expected (derived from Athaide, Meyers and Wilemon, 1996) and the extent to which the market agent sought to coordinate production plans (Ford, 1984).

Each of these measures was indicative of a long-term orientation and represented, on behalf of the market agent, a willingness to invest a significant amount of time in the relationship. Because of the relative ease with which growers could change market agents (since most growers dealt with more than one), these investments might have signalled to the growers a willingness on behalf of the market agent to make themselves vulnerable, thereby significantly reducing their perceived power to influence the relationship. The willingness to make relationship specific investments provided evidence that the partner could be believed, that it cared for the relationship and was willing to make sacrifices (Ganesan, 1994).

With the exception of one item measure that sought to evaluate the extent to which the market agent advised the grower of potential market demand (derived from Anderson and Narus, 1990), the various other item measures which sought to evaluate the day-to-day extent to which the market agent advised the grower of market prices or provided technical information cross loaded across several constructs and were deleted from further consideration.

Factor 3 (power/dependence) captured four item measures that evaluated the extent to which the preferred market agent had all the power in the relationship (Frazier, Gill and Kale, 1989) and controlled all the information. Since growers regularly transacted with more than one market agent and, in addition, since most growers sold some proportion of their harvest to 
alternative market outlets, growers were neither dependent on their market agent nor did they have to adhere to the market agent's demands.

Factor 4 (goal compatibility) was comprised of just two item measures; the extent to which the grower and the market agent discussed business goals (Morris, Brunyee and Page, 1998) and the extent to which they shared similar goals (Gundlach, Achrol and Mentzer, 1995). However, in contrast to the other measures of reliability, with a Cronbach's alpha of just 0.659 , the construct bordered on the minimum acceptable value of 0.7 (Nunnally, 1978). Nevertheless, given the exploratory nature of this research, it was considered acceptable.

Factor 5 (opportunism) was comprised of a single item measure: the extent to which the market agent often acted opportunistically (Anderson and Weitz, 1992).

Factor 6 (duration) was also comprised of a single item measure which was an indication of the length of time the grower had been transacting with their most preferred market agent (derived from Doney and Cannon, 1997).

The six principal components were then regressed against the single dependent variable (trust) using linear regression (Table 3).

Table 3. Results of regression analysis.

\begin{tabular}{|l|c|c|c|c|}
\hline & Beta & t & Sig. & Hypothesis \\
\hline Relational satisfaction & 0.764 & 20.081 & 0.000 & Accepted \\
\hline Goal compatibility & 0.277 & 7.281 & 0.000 & Accepted \\
\hline Relational investments & 0.272 & 7.144 & 0.000 & Accepted \\
\hline Power & -0.154 & -4.062 & 0.000 & Accepted \\
\hline Opportunism & -0.180 & -0.475 & 0.000 & Accepted \\
\hline Duration & 0.048 & 1.259 & 0.210 & Rejected \\
\hline & & & & \\
\hline Adjusted R ${ }^{2}=0.796$ & & & & \\
\hline Standard error $=0.456$ & & & & \\
\hline
\end{tabular}

A significant positive relationship between the grower's satisfaction with the exchange and the grower's trust in the market agent was confirmed. The large beta coefficient indicated that relational satisfaction had the most significant impact on building trust between the growers and their preferred market agent.

While the pursuit of compatible goals and the making of relationship-specific investments were also observed to have a significant positive impact on trust, the market agent's propensity to engage in opportunistic behaviour and to use coercive influence strategies had, as hypothesised, a significant negative impact on trust.

The duration of the relationship was the only construct found not to influence trust. 


\section{Discussion and implications}

A grower's satisfaction with the exchange transaction was found to have the most significant influence on building trust between the grower and their most preferred market agent. Growers were most satisfied when they believed they had been treated fairly and equitably, when the grower's expectations of what they should receive had been met and when growers felt adequately rewarded for their efforts. Such expectations may also have been related to product quality and the extent to which the grower believed the quality of the produce they consigned to the market was superior or inferior to the other produce offered for sale.

Whenever economic outcomes are higher than expected, growers may attribute a great deal of the credit to their market agent. In doing so, the grower's attraction to and trust in the preferred market agent will increase. Geyskens, Steenkamp and Kumar (1998) and Mackenzie and Hardy (1996) propose that as satisfaction increases, trust will increase. Since satisfaction is also inversely related to channel conflict (Frazier, 1983), the speed with which the market agent addressed the grower's complaints was found to lower the overall level of conflict in the relationship and thus to have a significant, positive impact on trust.

Since the majority of growers transact with more than one market agent and since most growers re-evaluate their relationship with their preferred market agent after each transaction, the grower's satisfaction with the exchange will be contingent upon their preferred market agent providing returns that are comparable to those achieved from competing market agents. Where there is some difference in the net price received between two or more market agents, the grower can be expected to allocate a greater proportion of their crop to that agent from whom they received the highest price. However, it is unlikely that small differences in the price received will cause the grower to abandon the relationship.

Satisfaction in long-term relationships is a cumulative experience, based on an overall evaluation of the purchase experience over time (Fornell, 1992). Whereas transaction-specific satisfaction may provide specific diagnostic information about a particular product or service encounter, cumulative satisfaction will provide an indication of the market agent's past, current and future performance. It is cumulative satisfaction that motivates firms to invest in customer satisfaction, for satisfaction is derived not only from the current experience, but also all past experiences, as well as all future or anticipated experiences (Anderson, Fornell and Lehmann, 1994). Consequently, relational satisfaction depends not only upon whether the market agent currently meets the grower's needs, but the anticipated quality of any future product and service encounters.

Contrary to expectations, there was no significant relationship between the duration of the relationship and trust between the growers and market agents. A more detailed examination of the duration of the grower's relationship with their preferred market agent indicated that $25 \%$ of growers had been trading with their preferred market agent for less than two years; $47 \%$ had been trading with their preferred market agent for fewer than 5 years and $60 \%$ had been trading with their preferred market agent for less than 8 years. As the duration of the relationship increased, the grower's trust in their preferred market agent was observed to decrease, suggesting a negative rather than a positive correlation between the duration of the relationship and trust. This would suggest that as the exchange partners became increasingly familiar with one another, the growers experience suggested that at some point in time, market agents would take advantage of them. 
As relationships are often conceptualised as an aggregation of historically inter-linked acts and episodes of exchange (Tikkanen, Alajoutsijarvi and Tahtinen, 2000), it is important to identify those critical incidents that directly influence satisfaction or dissatisfaction. Critical incidents represent aspects or points in time that potentially induce change in a relationship (Edvardsson and Strandvik, 2000). In the context of the fresh fruit and vegetable industry, small changes in the prices received are unlikely to be viewed by the grower as critical. However, over time, where the prices received are consistently lower than those offered by other agents, growers may begin to feel that their preferred market agent is no longer representing their best interests. Should the grower find, on closer examination, that the market agent has engaged in some opportunistic trading practice then invariably, this will have a significant negative impact on trust.

From the market agent's perspective, while the desire to pursue individual interests may lead to behaviour that is entirely rational, such will, in the longer term, lead to an outcome that will prove less than desirable. With trust undermined, growers will either withdraw from the relationship or seek to limit their commitment to it. Furthermore, growers can be expected to avoid entering into exchange relationships with those market agents who are perceived to act dishonestly. This would suggest that there must be some minimum level of trust present for the market agent to be considered as a potential exchange partner.

In order for the market agent to signal their trustworthiness and their intention to engage in long-term relationships with target growers, the making of relationship-specific investments was observed to have a significant positive impact on trust. These investments included assisting the grower to identify more suitable varieties for their growing environment, to advise the grower of potential product quality and customer service requirements, and to advise the grower of potential market demand. It might also mean attempting to coordinate or to adapt the grower's production to take advantage of those times in the market when prices were highest, or to produce a product to meet the specific requirements of a potential customer.

Adaptations are important because most business relationships are based on some kind of match between the operations of two firms (Hallen, Johanson and Seyed-Mohamed, 1991). When one or both parties make adaptations, they create various barriers to switching, making the relationship more durable (Moller and Wilson, 1995). Since adaptations also indicate the firm's willingness to accommodate the needs of its partner, they provide a signal of the extent to which that firm trusts its partner (Athaide, Meyers and Wilemon, 1996).

The final variable that was observed to have a significant positive relationship on trust was the extent to which the grower and the market agent shared similar goals. Long-term business relationships generally develop from the social exchange processes that occur between the individuals taking part in the transaction (Hakansson and Snehota, 1995). Relational norms evolve in exchange relationships when both parties contemplate bilaterally committed strategies and goals with a long-term orientation (Gundlach, Achrol and Mentzer, 1995). These norms include the extent to which unity or fellowship arising from common responsibilities and interests will dominate the relationship and the degree to which the monitoring of individual transactions is tempered by trust. For as long as both partners see their goals being met by joint action, they will be motivated to maintain the relationship (Wilson and Moller, 1995). 
While the loss of autonomy is often viewed as potentially threatening to the formation of close relationships, a close relationship does not mean that all conflict has been resolved; rather, some amount of conflict may be necessary to maintain the relationship between the two firms (Hakansson and Snehota, 1995). Conflict in channel relationships most often occurs over economic issues (Geyskens, Steenkamp amd Kumar, 1999). Channel partners that are highly satisfied with the economic rewards that flow from their relationship perceive their partner as advancing their goal attainment, as opposed to impeding or preventing it. Conversely, relational disagreements tend to elicit frustration, thereby causing feelings of unpleasantness, dissatisfaction with the relationship and eventually distrust towards the channel partner.

\section{Conclusions}

With the move away from the auction as the principal mechanism for establishing price in the fresh fruit and vegetable industry and the concomitant reduction in transparency associated with private negotiation, trust between growers and market agents is becoming increasingly important. Trust becomes important in an exchange when there is some uncertainty associated with the decision outcome and when the outcome is considered important.

In the context of the fresh produce industry, since prices are largely determined by supply and demand, there will always be some uncertainty as to what price the grower will ultimately receive for their produce. Market agents can attempt to reduce some of the price uncertainty and thereby generate greater trust by making various relationship-specific investments, whereupon they advise growers in advance of what quantities and quality of produce are required by customers. Market agents can also advise growers of what varieties are in greatest demand and assist them on-farm to improve the quality of the produce they offer for sale.

The market agent's willingness to work with the grower will not only signal their desire to enter into a long-term relationship, but may also signal a greater willingness to pursue mutually beneficial goals. Sharing sensitive market information will not only improve transparency in the exchange, but also signal the market agents desire to cooperate and collaborate.

Understandably, since growers usually transact with more than one market agent, market agents may question the value in investing their time and effort to improve performance when they are not the sole recipients. However, in what is a highly competitive market, if one market agent does not make the investment, another probably will. Thus, in order to retain their market share, it would seem that market agents must endeavour to build long-term relationships with growers.

While it is widely accepted that trust leads to a strong desire to maintain a relationship (Anderson and Narus, 1990; Gundlach, Achrol and Mentzer, 1995), growers have indicated that the major reason for continuing to trade with their preferred market agent is the expectation of high returns. Since satisfaction with the exchange is derived primarily from the extent to which the growers expectations are fulfilled, satisfaction is also posited to have a direct influence on the growers desire to maintain their relationship with their most preferred market agent. Whether it is trust or simply the grower's satisfaction with the exchange that is the predominant force impacting on the growers desire to maintain their relationship with their preferred market agent warrants further investigation. Since growers can readily switch 
between alternative market agents, there is the danger that while market agents may invest in building long-term relationships growers will continue to pursue a more transactional approach to the marketing of their produce.

Irrespective, in order to maintain their relationship with growers, market agents must refrain from participating in any exchange transactions that might be perceived as opportunistic. Over time and as familiarity with one another grows, market agents may be tempted to seek to extract additional margins perhaps to cover some of the costs of maintaining the relationship. However, should such opportunism be detected, growers will also certainly terminate the relationship and the value of these investments will be lost. Since growers also communicate among themselves, those market agents who have been found to engage in opportunistic trading will need to work harder to prevent other growers from switching.

However, in who does the grower trust; the salesperson or the sales organisation? While the term market agent has been used throughout this paper, it could be interpreted to mean both the individual and the organisation. Moorman, Desphande and Zaltman (1993) and Swan, Trawick and Silva (1985) describe the various interpersonal factors that affect trust. Conversely, Morgan and Hunt (1994) describe how people develop trust in an organisation. Doney and Cannon (1997) suggest that customers can trust the firm, its sales representatives or both. Since one of the reasons growers gave for leaving their preferred market agent was because the sales representative had resigned to join another firm, this would suggest that personal relationships are important in building trust in the fresh produce industry. However, the various item measures used throughout this study were unable to differentiate between trust in the individual and trust in the organisation. As most market agents in the Perth Metropolitan Market are relatively small family based organisations, it will prove very difficult to make this distinction.

\section{Acknowledgements}

In the final preparation and presentation of this paper, the author wishes to acknowledge and thank the two anonymous reviewers for their constructive criticism of earlier drafts.

\section{References}

Achrol, R. S. (1997), "Changes in the Theory of Interoganisational Relations in Marketing: Toward a Network Paradigm”, Journal of the Academy of Marketing Science. Vol 25 No. 1, pp 56-71.

Anderson, E., Chu, W. and Weitz, B.A. (1987), "Industrial Purchasing: An Empirical Exploration of the Buyclass Framework”, Journal of Marketing, Vol. 51 July, pp 71-86.

Anderson, E.W., Fornell, C. and Lehmann, D.R. (1994), “Customer Satisfaction, Market Share and Profitability: Findings from Sweden”, Journal of Marketing, Vol 58 July, pp 53-66.

Anderson, E. and Weitz, B.A. (1989), "Determinants of Continuity in Conventional Industrial Channel Dyads”, Marketing Science, Vol. 8 Fall, pp 310-323. 
Anderson, E. and Weitz, B.A. (1992), “The Use of Pledges to Build and Sustain Commitment in Distribution Channels”, Journal of Marketing Research, Vol. 29 February, pp 18-34.

Anderson, J. C. and Narus, J.A. (1990), “A Model of Distributor Firm and Manufacturing Firm Working Relationships”, Journal of Marketing, Vol. 54 January, pp 42-58.

Armstrong, J.S and Overton, T. (1977), “Estimating Non Response Bias in Mail Surveys”, Journal of Marketing Research, Vol. 14 August, pp 396-402.

Athaide, G. A., Meyers, P.W. and Wilemon, D.L. (1996), “Seller-Buyer Interactions During the Commercialisation of Technological Process Innovations”, Journal of Product Innovation Management, Vol. 13, pp 406-421.

Brenkert, G.G. (2000), “Trust, Morality and International Business”, in Lane, C. and Bachmann, R. (ed) Trust Within and Between Organisations. Oxford University Press. pp 273-297.

Caddy, J. (1978), Perth Markets, Metropolitan Market Trust.

Campbell, A.J. and Wilson, D.T. (1996), "Managed Networks: Creating Strategic Advantage” in Iacobucci, D. (ed), Networks in Marketing. Sage Publications. pp 125-143.

Chamber of Fruit and Vegetable Industries (1999). Submission to the Review of the Perth Market Act (1926). Part 1. Transparency.

Cronbach, L.J. (1951), “Coefficient Alpha and the Internal Structure of Tests”, Psychometrica, Vol. 16, pp 297-334.

Cunningham, M.T. and White, J.G. (1973), “The Determinants of Choice of Supplier”, European Journal of Marketing. Vol 7 Winter, pp 189-202.

Doney, P.M. and Cannon, J.P. (1997), “An Examination of the Nature of Trust in BuyerSeller Relationships”, Journal of Marketing, Vol. 61 April, pp 35-51.

Dwyer, F.R., Schurr, P.H. and Oh, S. (1987), “Developing Buyer-Seller Relationships”, Journal of Marketing. Vol. 51 April, pp 11-27.

Easton, G. and Araujo, L. (1994), "Market Exchange, Social Structures and Time”, European Journal of Marketing, Vol 28 No. 3, pp 72-84.

Edvardsson, B. and Strandvik, T. (2000), "Is a Critical Incident Critical for a Customer Relationship?” Managing Service Quality, Vol 10 No. 2, pp 82-91.

Ford, D. (1984), “Buyer/Seller Relationships in International Industrial Markets”, Industrial Marketing Management, Vol. 13, pp 101-112.

Ford, D., McDowell, R. and Tomkins, C. (1996), "Relationship Strategy, Investments and Decision Making”, in Iacobucci, D. (ed), Networks in Marketing, Sage Publications, pp 144176. 
Fornell, C. (1992), “A National Customer Service Barometer: the Swedish Experience”, Journal of Marketing, Vol. 55 January, pp 1-21.

Frazier, G.L. (1983), “Interorganisational Exchange Behaviour in Marketing Channels: A Broadened Perspective”, Journal of Marketing, Vol. 47 Fall, pp 68-78.

Frazier, G.L., Gill, J.D. and Kale, S.H. (1989), "Dealer Dependence Levels and Reciprocal Actions in a Channel of Distribution in a Developing Country”, Journal of Marketing,Vol. 53 January, pp 50-69.

Ganesan, S. (1994), “Determinants of Long-Term Orientation in Buyer-Seller Relationships”, Journal of Marketing, Vol. 58 April, pp 1-19.

Geyskens, I., Steenkamp, J.B and Kumar, N. (1998), “Generalisations About Trust in Marketing Channel Relationships Using Meta-Analysis”, International Journal of Research in Marketing, Vol 15 No. 3, pp 223-248.

Geyskens, I., Steenkamp, J.B. and Kumar, N. (1999), "A Meta-Analysis of Satisfaction in Marketing Channel Relationships”, Journal of Marketing Research, Vol. 36 May, pp 223238.

Gundlach, G.T., Achrol, R.S. and Mentzer, J.T. (1995), “The Structure of Commitment in Exchange”, Journal of Marketing, Vol. 59 January, pp 78-92.

Hakansson, H. and Sharma, D.D. (1996), "Strategic Alliances in a Network Perspective”, in Iacobucci, D. (ed), Networks in Marketing, Sage Publications, pp 108-124.

Hakansson, H. and Snehota, I. (1995), Developing Relationships in Business Networks. International Thomson Business Press. London.

Hallen, L., Johanson, J. and Seyed-Mohamed, N. (1991), "Interfirm Adaptation in Business Relationships”, Journal of Marketing, Vol 55 April, pp 29-37.

Halstead, D. (1999), “The Use of Comparison Standards in Customer Satisfaction Research and Management: A Review and Proposed Typology”, Journal of Marketing Theory and Practice, Vol 7, No. 3, pp 13-26.

Hawes, J.M., Mast, K.E. and Swan, J.E. (1989), “Trust Earning Perceptions of Sellers and Buyers”, Journal of Personal Selling and Sales Management, Vol 9 Spring, pp 1-8.

Heide, J.B. and John, G. (1988), “The Role of Dependence Balancing in Safe-Guarding Transaction-Specific Assets in Conventional Channels”, Journal of Marketing. Vol 52 January, pp 20-35.

Heide, J.B. and John, G. (1990), “Alliances in Industrial Purchasing: The Determinants of Joint Action in Buyer-Seller Relationships”, Journal of Marketing Research, Vol 28 February, pp 24-36. 
Humphrey, J. (2000), “Trust and the Transformation of Supplier Relations in Indian Industry” in Lane, C and Bachmann, R. (ed). Trust Within and Between Organisations. Oxford University Press. pp 214-240.

Jackson, B. B. (1985), “Build Customer Relations That Last”, Harvard Business Review, November-December, pp 120-128.

Kalwani, M.U. and Narayandas, N. (1995), “Long-Term Manufacturer-Supplier Relationships: Do They Pay Off for Supplier Firms?”, Journal of Marketing. Vol 59 January, pp 1-16.

Kumar, N. (1996), “The Power of Trust in Manufacturer-Retailer Relationships”, Harvard Business Review, November-December, pp 92-106.

Lane, C. (2000). "Introduction: Theories and Issues in the Study of Trust”, in Lane, C and Bachmann, R. (ed). Trust Within and Between Organisations. Oxford University Press. pp 130.

Lohtia, R. and Krapfel, R.E. (1994), “The Impact of Transaction-Specific Investments on Buyer-Seller Relationships”, Journal of Business and Industrial Marketing. Vol 9, No. 1, pp 6-16.

Luhmann, N. (1979). Trust and Power. Chichester. Wiley.

Mackenzie, H.F and Hardy, K.G. (1996), "Manage Your Offering or Manage Your Relationship?”, Journal of Business and Industrial Marketing, Vol 11 No. 6, pp 20-37.

McQuiston, D.H. (2001), “A Conceptual Model for Building and Maintaining Relationships between Manufacturers’ Representatives and Their Principals”, Industrial Marketing Management, Vol 30, pp 165-181.

Mayer, R.C., Davis, J.H and Schoorman, F.D. (1995), “An Integrative Model of Organisational Trust”, Academy of Management Review, Vol 20 No. 3, pp 709-734.

Moller, K. and Wilson, D.T. (1995), “Business Relationships. An Interaction Perspective”, in Moller, K. and Wilson, D.T. (ed). Business Marketing: An Interaction and Network Perspective. Kluwer Academic Publishers. pp 23-52.

Moorman, C., Deshpande, R. and Zaltman, G. (1993), “Factors Affecting Trust in Market Research Relationships”, Journal of Marketing. Vol 57 January, pp 81-101.

Morgan, R.M. and Hunt, S.D. (1994), "The Commitment-Trust Theory of Relationship Marketing”, Journal of Marketing. Vol 58 July, pp 20-38.

Morris, M.H., Brunyee, J. and Page, M. (1998), "Relationship Marketing in Practice. Myths and Reality”, Industrial Marketing Management, Vol 27, pp 359-371.

Nunnally, J.C. (1978), Psychometric Theory. Second Ed. McGraw Hill. New York. 
Oliver, R.L. (1980), “A Cognitive Model of the Antecedents and Consequences of Satisfaction Decisions”, Journal of Marketing Research, Vol 17 November, pp 460-69.

Parkhe, A. (1993), "Strategic Alliance Structuring: A Game Theoretic and Transaction Cost Examination of Interfirm Cooperation”, Academy of Management Journal, Vol 36 No. 4, pp 794-829.

Pfeffer, J. and Salancik, G.R. (1978), The External Control of Organisations: A ResourceDependence Perspective. Harper and Row. New York.

Ring, P.S. and van de Ven, A.H. (1992), "Structuring Cooperative Relationships Between Organisations”, Strategic Management Journal, Vol 13. No. 7, pp 483-498.

Sako, M. (1992), Prices, quality and trust: inter-firm relations in Britain and Japan. Cambridge University Press.

Selnes, F. (1998), “Antecedents and Consequences of Trust and Satisfaction in Buyer-Seller Relationships”, European Journal of Marketing, Vol 32 No. 3/4, pp 305-322.

Spekman, R.E. and Celly, K.S. (1995), “Towards an Understanding of the Antecedents of Strategic Alliances”, in Moller, K and Wilson, D. (ed). Business Marketing: An Interaction and Network Perspective. Kluwer Academic Publishers. pp 157-191.

Swan, J.E., Trawick, I.F. and Silva, D.W. (1985), "How Industrial Salespeople Gain Customer Trust”, Industrial Marketing Management, Vol 14, pp 203-211.

Tikkanen, H., Alajoutsijarvi, K. and Tahtinen, J. (2000), “The Concept of Satisfaction in Industrial Markets: A Contextual Perspective and a Case Study from the Software Industry”, Industrial Marketing Management, Vol 29, pp 373-386.

Tomkins, C. (2001), “Interdependencies, Trust and Information in Relationships, Alliances and Networks”, Accounting, Organisations and Society, Vol 26, pp 161-191.

Weylman, C.R. (1996), "Principles to Set Your Professional Reputation By”, National Underwriter, March 11, pp 21-23.

Williamson, O.E. (1985), The Economic Institutions of Capitalism. The Free Press. New York.

Wilson, D.T. (1995), “An Integrated Model of Buyer-Seller Relationships”, Journal of Academy of Marketing Science, Vol 23 No. 4, pp 335-345.

Wilson, D.T. and Moller, K. (1995), “Dynamics of Relationship Development” in Moller, K. and Wilson, D.T. (ed). Business Marketing: An Interaction and Network Perspective. Kluwer Academic Publishers. pp 53-69.

Zucker, L.G. (1986), "Production of Trust: Institutional Sources of Economic Structure, 18401920”, Research in Organisational Behaviour, Vol 8, pp 53-111. 